\title{
Mercury, organic-mercury and selenium in small cetaceans in Taiwanese waters
}

\author{
Meng-Hsien Chen ${ }^{\mathrm{a}, *}$, Chieh-Chih Shih ${ }^{\mathrm{a}}$, Chiu Long Chou ${ }^{\mathrm{a}, 1}$, Lien-Siang Chou ${ }^{\mathrm{b}}$ \\ ${ }^{a}$ Department of Marine Resources, National Sun Yat-sen University, Kaohsiung 804, Taiwan, ROC \\ ${ }^{\mathrm{b}}$ Department of Zoology, National Taiwan University, Taipei 106, Taiwan, ROC
}

\begin{abstract}
Total $\mathrm{Hg}\left(\sum \mathrm{Hg}\right)$, organic-Hg $(\mathrm{O}-\mathrm{Hg})$ and Se bioaccumulations in small cetaceans distributed in Taiwanese waters of the Taiwan Strait and the southwestern Pacific have been investigated for the first time. The results could represent the baseline metal concentrations of marine mammals in the southwestern Pacific, where volcanic activities are possibly the major source of mercury to the environments. Muscle samples of four species of small cetaceans were collected from animals accidentally caught by tuna-longline fisheries from 1994 through 1995. In total, 53 pantropical spotted dolphins, Stenella attenuata, nine spinner dolphins, S. longirostris, five bottlenose dolphins, Turiops truncatus and four Risso's dolphins, Grampus giseus were analyzed. In addition, two stranded pantropical spotted dolphins were investigated. Cold vapour AAS and ICP-MS were used in the analysis of Hg and Se, respectively. Significant species difference was found in the four species of small cetaceans. Among them, the pantropical spotted dolphin showed the highest mean concentration (mg/kg wet wt.) of both $\sum \mathrm{Hg}(3.64 \pm 2.19)$ and $\mathrm{O}-\mathrm{Hg}(2.79 \pm 1.23)$, whereas the Risso's dolphin had the highest mean concentrations of Se $(1.77 \pm 1.29)$. There was no significant sex difference with respect to metal bioaccumulation in the samples of $S$. attenuata. Significant correlations between body length (BL) and $\sum \mathrm{Hg}$, as well as $\mathrm{O}-\mathrm{Hg}$ concentrations were observed in pantropical spotted $(\mathrm{Sa})$ and spinner dolphins $(\mathrm{Sl})$. The linear relationships were $\mathrm{Sa}: \sum \mathrm{Hg}=-8.290+$ $0.066 \mathrm{BL}, r=0.421 ; \mathrm{Sl}: \sum \mathrm{Hg}=-2.735+0.025 \mathrm{BL}, r=0.875 ; \mathrm{Sa}: \mathrm{O}-\mathrm{Hg}=-3.723+0.036 \mathrm{BL}, r=0.408 ;$ and $\mathrm{Sl}: \mathrm{O}-\mathrm{Hg}=$ $-3.017+0.025 \mathrm{BL}, r=0.870$. However, a demethylation phenomenon that decreasing the percentage of $\mathrm{O}-\mathrm{Hg}$ coupled with increasing levels of Se was observed when the $\sum \mathrm{Hg}$ concentrations in the muscle tissues of dolphins reached $4 \mathrm{mg} / \mathrm{kg}$ wet wt.
\end{abstract}

(C) 2002 Elsevier Science Ltd. All rights reserved.

Keywords: Pantropical spotted dolphin (Stenella atteunuata); Spinner dolphin (S. longirostris); Bottlenose dolphin (Turiops truncatus); Risso's dolphin (Grampus giseus); Background levels; Taiwan

\section{Introduction}

The Kuroshio Current flows through the eastern coast of Taiwan all year round, and resulting disturbance of the waters makes them rich in plankton, which then attracts many marine creatures feeding in this area. Meanwhile, migratory marine organisms, such as dolphins and tuna, chase their prey in the current, thereby creating a flourishing tuna fishery in the eastern and southwestern waters. Due to such nature, dolphins are

\footnotetext{
${ }^{*}$ Corresponding author: Tel: +886-7-525-2000x5028; fax: $+886-7-$ 525-5020.

E-mail address: mhchen@mail.nsysu.edu.tw (M.-H. Chen).

${ }^{1}$ Present address: Department of Fisheries and Oceans, Bedford Institute of Oceanography, Maritime Region, P.O. Box 1006, Dartmouth, NS, Canada B2Y 4A2.
}

most often found among tuna cruising in the sea, which frequently leads to their getting entangled in fishing nets. Not until 1994, however, had such an abundance of small-toothed cetacean ever been studied in Taiwan. The Cetacean Research Team was consequently established in the Department of Zoology at National Taiwan University, and these entangled dolphins, therefore, became their research specimens. Once landed in the fishing ports, the carcasses of the accidentally caught cetaceans were handed over to police authorities so that they could be used by researches for investigative purposes. This marked the first time that the bioaccumulation of contaminants in the small cetaceans of Taiwan had ever been studied.

The toothed cetacean, inhabitants of the highest trophic levels of a marine ecosystem due to the food chain effect and their long longevity, bioaccumulate the 
greatest amount of various pollutants, such as organochlorines and mercury (Kemper et al., 1994; Aguilar et al., 1993; Leonzio et al., 1992; Andre et al., 1990). Generally, they are considered the end point of the biogeochemical cycle of mercury in the biological phase of a marine ecosystem (Becker, 2000; Bargagli et al., 1998; Becker and Bigham, 1995). Besides Taiwanese waters, the accumulation of mercury and other heavy metals in marine mammals has been examined in many areas and in various species (e.g. Siebert et al., 1999; Parsons, 1999; Holsbeek et al., 1998; Wagemann et al., 1996; Wood and Van Vleet, 1996; Noda et al., 1995; Law et al., 1991; Andre et al., 1991; Marcovecchio et al., 1990; Morris et al., 1989; Fujise et al., 1988). Therefore, it is worthwhile to use all of these findings as diagnostic and comparative tools to understand the status of marine pollution in Taiwanese waters (Marcovecchio et al., 1994; Miyazaki, 1994; Viale, 1994; Fujise et al., 1988). Moreover, by gaining a better understanding of the bioaccumulation pattern in the marine mammal, we may well be able to gain insight into the transfer and fate of mercury in the biogeochemical cycle.

\section{Materials and methods}

From 1994 to 1995, we collected samples of small cetaceans from police-detained dolphins which had accidentally been captured by tuna-angling fisheries around Taiwanese waters, mainly from Penghu, Suao, Chengkung, Tungkang, Kaohsiung and Yunlin (Fig. 1). The samples included 53 pantropical spotted dolphins (Stenella atteunuata), four Risso's dolphins (Grampus giseus), nine spinner dolphins ( $S$. longirostris) and five bottlenose dolphins (Turiops truncatus). In addition, two stranded pantropical spotted dolphins were also investigated in this study. As accurately as possible, the sizes of the samples were recorded for total length $(\mathrm{cm})$ and for body weight $(\mathrm{kg})$. Then $0.5-1 \mathrm{~kg}$ of muscle tissue at the flank under the dorsal fin was taken and frozen at $-20{ }^{\circ} \mathrm{C}$ for further analysis.

After thawing of samples, the outer-most layer of tissue was cut off to eliminate any contamination that may have occurred during field sampling. At this stage all of the equipment used had obviously been acidwashed and was ultra-clean. The samples were then cut into small cubes, homogenized and stored in small vials and refrozen at $-20{ }^{\circ} \mathrm{C}$ for further investigation.

The analysis of total mercury employed the method established in previous studies (Chen and Chou, 2000; Uthe et al., 1970, 1972). Briefly, 0.2-0.5 g of the homogenized flesh muscle tissues were weighed and placed into the $75 \mathrm{ml}$ graduated test tubes. One $\mathrm{ml}$ of nitric acid $\left(\mathrm{HNO}_{3}\right), 4 \mathrm{ml}$ of sulfuric acid $\left(\mathrm{H}_{2} \mathrm{SO}_{4}\right)$ and $15 \mathrm{ml}$ of potassium permanganate $\left(\mathrm{KMnO}_{4}\right)$ were used for wet digestion. Once the digestion was completed, each

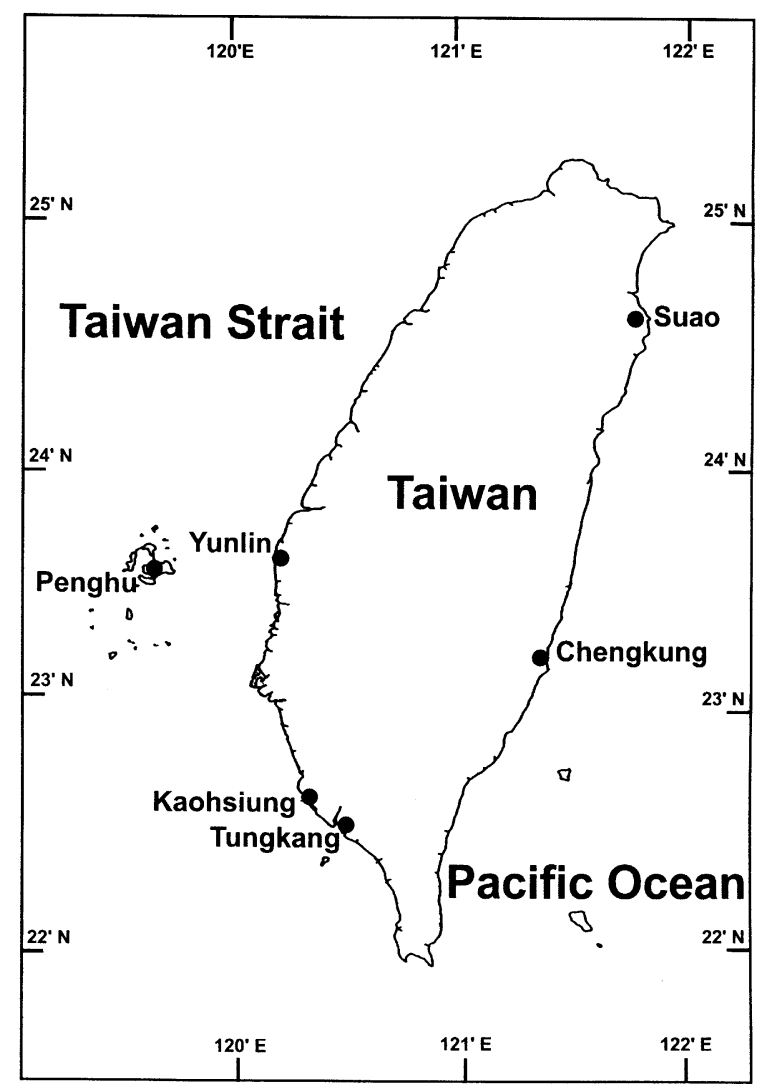

Fig. 1. Map showing the sampling sites of the cetaceans studied here.

sample was made up to $25 \mathrm{ml}$ of volume. By using $2 \%$ of tin(II) chloride dihydrate $\left(\mathrm{SnCl}_{4}\right)$ as a reductant, the measurement of $\mathrm{Hg}$ concentration was performed by cold vapour of an atomic absorption spectrophotometer (cold vapour AAS, Hitachi Z-8200 and HFS-2).

The organic-mercury extract method was adopted from Shum et al. (1979). First, acetone was used to remove lipid. Then, $5 \mathrm{ml} 3 \mathrm{M}$ potassium bromide $(\mathrm{KBr})$, with $10 \mathrm{ml} 0.1 \mathrm{M}$ copper sulfate $\left(\mathrm{CuSO}_{4}\right)$ as an extracting agent, was added to $0.3-0.5 \mathrm{~g}$ of homogenized flesh muscle in $40 \mathrm{ml}$ conical graduated centrifuge tubes. The extractant was put into $20 \mathrm{ml}$ centrifuge tubes and extracted with toluene again and the upper organic phase was taken into another $20 \mathrm{ml}$ centrifuge tubes. Finally, the organic phase of $\mathrm{Hg}$ was then extracted back to $1 \mathrm{ml} 0.005 \mathrm{M}$ sodium persulfate $\left(\mathrm{Na}_{2} \mathrm{~S}_{2} \mathrm{O}_{3}\right)$ and this $1 \mathrm{ml} \mathrm{Na}{ }_{2} \mathrm{~S}_{2} \mathrm{O}_{3}$ extractant was transferred into a 75 $\mathrm{ml}$ test tube. Then, once again the $\mathrm{Hg}$ digestion procedure was performed, as previously stated, and the $\mathrm{Hg}$ concentration was also measured using cold vapour AAS method.

For the analysis of Se, approximately $1 \mathrm{~g}$ of homogenized flesh muscle was weighed and put into a 50 $\mathrm{ml}$ conical flask to which $10 \mathrm{ml}$ nitric acid was added for acid digestion. When the tissue was completely dissolved, it was gradually heated to $120^{\circ} \mathrm{C}$ on a hot plate 
until the vapour and acid flume inside the flask turned clear. After the excess acid had evaporated, the sample was washed with $1 \mathrm{M} \mathrm{HNO}_{3}$ and filtrated through Whatman No. 540 filter paper. Finally, the filtrated digests were quantified into $25 \mathrm{ml}$ volumetric flasks. This sample was then ready for analysis using inductively coupled plasma mass spectrometry (ICP-MS PerkinElmer Eln 500).

Each sample was analyzed at least in duplicate and measured at least twice. Regent blanks were inserted in every 20th sample to detect any alien contaminant. In addition, the duplicates of the standard reference material (DORM-2, Dog fish muscle purchased from the National Research Council of Canada) were analyzed simultaneously in each digesting process. All chemical reagents used in this study were GR grade from Merck Company Ltd. The instrumental detection limits of $\sum \mathrm{Hg}, \mathrm{O}-\mathrm{Hg}$ and $\mathrm{Se}$ were calculated based on three standard deviation of blank after a series of analyses. They were 1, 2 and $1 \mathrm{ng} / \mathrm{ml}$, respectively. Our analytical results of DORM-2 were $\mathrm{Hg}=4.69 \pm 0.25(n=20)$, $\mathrm{O}-\mathrm{Hg}=4.39 \pm 0.43(n=20)$ and $\mathrm{Se}=1.51 \pm 0.19(n=4)$ $\mathrm{mg} / \mathrm{kg}$ dry wt. Compared with the certified values of DORM-2, i.e. $\mathrm{Hg}=4.64 \pm 0.26, \mathrm{O}-\mathrm{Hg}=4.47 \pm 0.32$ and $\mathrm{Se}=1.40 \pm 0.09 \mathrm{mg} / \mathrm{kg}$ dry wt., the recovery rates in this study were within $100 \pm 10 \%$.

The statistical analysis was performed using SAS software, including Student's $t$-test, linear regression, ANOVA (one-way analysis of variance, $p<0.05$ ) and ANCOVA (analysis of covariance, $p<0.01$ ). The Duncan's multiple-range test was also adopted to detect differences in metal concentrations among the four species $(p<0.05)($ SAS, 1988).

\section{Results}

Significant species differences in terms of concentrations of $\sum \mathrm{Hg}, \mathrm{O}-\mathrm{Hg}$ and $\mathrm{Se}$ in muscle tissues were obvious among the four species of small cetaceans (Fig. 2). For one, S. attenuata showed the highest means of both $\sum \mathrm{Hg}(3.64 \pm 2.21 \mathrm{mg} / \mathrm{kg}$ wet wt. $)$ and $\mathrm{O}-\mathrm{Hg}(2.81 \pm$ $1.24 \mathrm{mg} / \mathrm{kg}$ wet wt.). Its $\mathrm{O}-\mathrm{Hg}$ value was significantly higher than that of the spinner and bottlenose dolphins. On the other hand, the G. giseus had the highest mean Se concentration $(1.77 \pm 1.29 \mathrm{mg} / \mathrm{kg}$ wet wt.) and differed significantly from $T$. truncatus. The lowest mean $\sum \mathrm{Hg}(1.39 \pm 0.30 \mathrm{mg} / \mathrm{kg}$ wet wt.) and mean $\mathrm{O}-\mathrm{Hg}$ $(1.13 \pm 0.32 \mathrm{mg} / \mathrm{kg}$ wet wt.) concentrations were apparent in $S$. longirostris while the lowest mean Se concentration $(0.92 \pm 0.27 \mathrm{mg} / \mathrm{kg}$ wet wt.) was found in $T$. truncatus (Fig. 2).

No significant sex difference with regard to metal bioaccumulation was observed in males and females of $S$. attenuata (Student's $t$-test, $p>0.05$ ). Compared with the by-catch samples, the two stranded samples (one

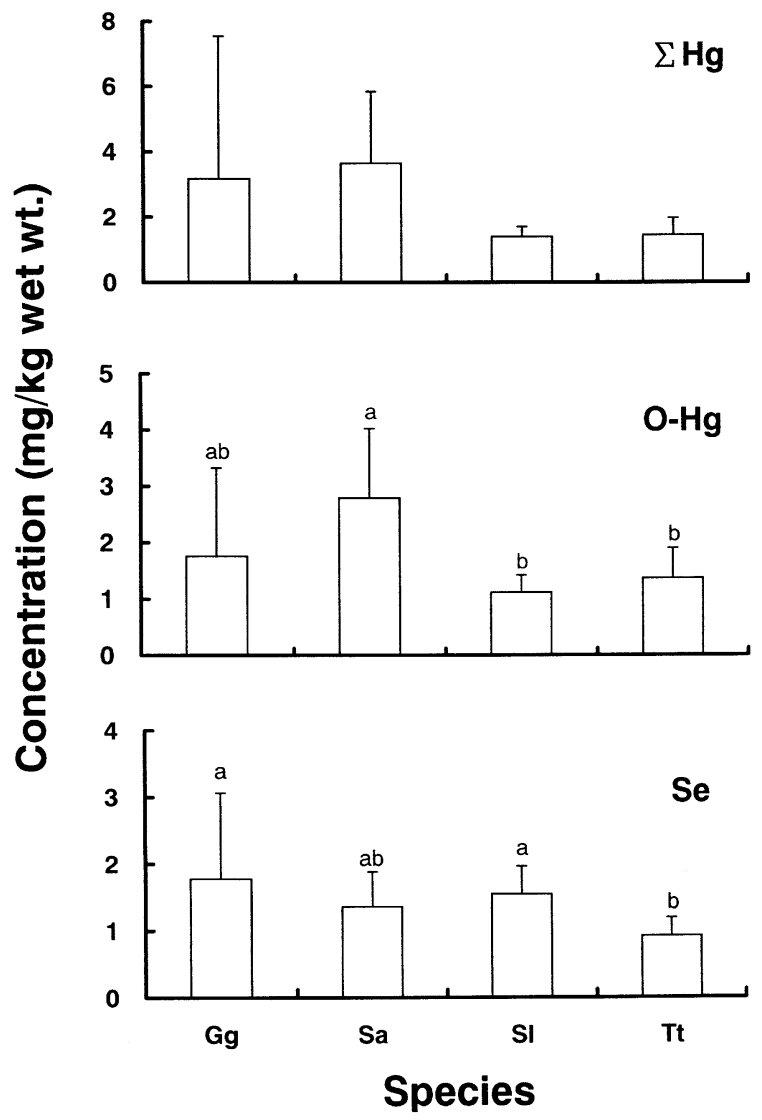

Fig. 2. Means and standard deviations of $\sum \mathrm{Hg}, \mathrm{O}-\mathrm{Hg}$ and Se concentrations $(\mathrm{mg} / \mathrm{kg}$ wet wt.) of muscle tissues in four species of cetaceans. Gg: Risso's dolphin, G. giseus; Sa: pantropical spotted dolphin, $S$. atteunuata; Sl: spinner dolphin, $S$. longirostris; and Tt: bottlenose dolphin, T. truncatus. The symbols $\mathrm{a}, \mathrm{ab}, \mathrm{b}$ and $\mathrm{c}$ above the vertical bars show the results of Duncan's multiple-range test and indicate that there is no significant difference with same italic letter.

male and one female) did not show any elevated metal levels (Tables 1 and 2).

Significant correlations between body length and metal concentrations of $\sum \mathrm{Hg}$ and $\mathrm{O}-\mathrm{Hg}$ were noted in both S. attenuata and S. longirostris (Fig. 3). However, the linear relationship between the female and male $S$. attenuata was not significant (ANCOVA, $p>0.05$ ). Therefore, it was combined as $\mathrm{Sa}: \sum \mathrm{Hg}=-8.290+$ 0.066BL, $r=0.421$; $\mathrm{Sl}: \sum \mathrm{Hg}=-2.735+0.025 \mathrm{BL}, r=$ 0.875 ; $\mathrm{Sa}: \mathrm{O}-\mathrm{Hg}=-3.723+0.036 \mathrm{BL}, r=0.408$; and Sl: $\mathrm{O}-\mathrm{Hg}=-3.017+0.025 \mathrm{BL}, r=0.870$ (Fig. 3). A good correlation between body length and Se concentrations was only found in $S$. longirostris $(\mathrm{Se}=-1.268+$ $0.017 \mathrm{BL}$ ), but this was not the case with $S$. attenuata (Fig. 3).

Organic-mercury in both $S$. attenuata and $S$. longirostris significantly correlated with total mercury. However, two regression lines were noted in S. attenu$a t a$, whereas only one was fitted in the case of the $S$. longirostris (Fig. 4). In S. attenuata, the turning point was at $4 \mathrm{mg} / \mathrm{kg}$ of $\sum \mathrm{Hg}$. A comparison of the regression 
Table 1

Means and standard deviations of body length $(\mathrm{BL})$, total mercury $\left(\sum \mathrm{Hg}\right)$, organic-mercury $(\mathrm{O}-\mathrm{Hg})$ and selenium $(\mathrm{Se})$ concentrations $(\mathrm{mg} / \mathrm{kg}$ wet wt.) in males and females by-catch Pantropical spotted dolphins, S. attenuata, as well as stranded Pantropical spotted dolphins

\begin{tabular}{lllllll}
\hline Source & Sex & No. & BL $(\mathrm{cm})$ & $\sum \mathrm{Hg}$ & $\mathrm{O}-\mathrm{Hg}$ & $\mathrm{Se}$ \\
\hline Stranded in Penghu, September 1995 & Male & 1 & 150 & 0.55 & 0.54 & 0.88 \\
Stranded in Penghu, October 1995 & Female & 1 & 191 & 5.58 & 2.11 & 0.64 \\
By-catch in Suao, Yunlin and Tungkang & Male & 21 & 179 & $3.46 \pm 1.92$ & $2.81 \pm 1.46$ & $1.35 \pm 0.43$ \\
& & & $(160-205)$ & $(1.27-8.23)$ & $(1.07-7.53)$ & $(0.76-2.55)$ \\
By-catch in Suao, Yunlin, Tungkang and & Female & 32 & 180 & $3.76 \pm 2.38$ & $2.77 \pm 1.09$ & $1.36 \pm 0.58$ \\
Chengkung & & & $(158-242)$ & $(1.05-12.03)$ & $(1.05-4.87)$ & $(0.90-4.19)$ \\
\hline
\end{tabular}

Table 2

Means and standard deviations of total mercury ( $\left.\sum \mathrm{Hg}\right)$, organic-mercury $(\mathrm{O}-\mathrm{Hg}$ ) and selenium (Se) concentrations (mg/kg wet wt.) in the muscle tissues of various small dolphins all over the world

\begin{tabular}{|c|c|c|c|c|c|}
\hline Species & Region & $\sum \mathrm{Hg}$ & $\mathrm{O}-\mathrm{Hg}$ & $\mathrm{Se}$ & Reference \\
\hline \multirow{3}{*}{ Grampus griseus } & Taiwan Strait \& SW & $3.17 \pm 4.36$ & $2.00 \pm 1.42$ & $1.77 \pm 1.29$ & This study \\
\hline & Pacific & $(0.71-9.70)$ & $(0.97-4.05)$ & $(0.78-3.63)$ & \\
\hline & Mediterranean, Italy & $(26.52-30.87)$ & $(15.0-15.7)$ & $(6.5-17.3)$ & Storelli et al. (1998) \\
\hline \multirow{2}{*}{$\begin{array}{l}\text { Lagenorhynchus albi- } \\
\text { rostris }\end{array}$} & Newfoundland, NW & $0.41 \pm 0.11$ & - & $0.48 \pm 0.23$ & Muir et al. (1988) \\
\hline & Atlantic & $(0.175-0.65)$ & & $(0.30-1.20)$ & \\
\hline \multirow[t]{2}{*}{ Phocoena phocoena } & Cardigan Bay, W. Wales* & $(0.22-1.1)$ & - & - & Morris et al. (1989) \\
\hline & $\begin{array}{l}\text { North and Baltic Sea, } \\
\text { Germany* }\end{array}$ & $3.5 \pm 14.4(0.2-108)$ & $\begin{array}{l}0.9 \pm 0.9 \\
(0.1-5.3)\end{array}$ & - & Siebert et al. (1999) \\
\hline Phocoenoides dalli & $\begin{array}{l}\text { Northwestern Pacific, } \\
\text { Japan }\end{array}$ & (NA-1.13) & - & - & Fujise et al. (1988) \\
\hline \multirow[t]{4}{*}{ Stenella attenuata } & Taiwan Strait \& SW & $3.64 \pm 2.21$ & $2.81 \pm 1.24$ & $1.36 \pm 0.52$ & This study \\
\hline & Pacific & $(1.05-12.0)$ & $(1.05-7.53)$ & $(0.76-4.19)$ & \\
\hline & Australian waters & $(0.82-1.01)$ & - & - & Kemper et al. (1994) \\
\hline & $\begin{array}{l}\text { Eastern tropical } \\
\text { Pacific }\end{array}$ & $2.27(0.1-9.17)$ & - & - & Andre et al. (1991) \\
\hline \multirow[t]{8}{*}{ S. coeruleoalba } & Cardigan Bay, W. Wales* & 0.56 & - & - & Morris et al. (1989) \\
\hline & $\begin{array}{l}\text { Atlantic, France } \\
(1972-1980)^{*}\end{array}$ & $3.76(1.50-12.00)$ & - & - & Andre et al. (1990) \\
\hline & $\begin{array}{l}\text { Kawana \& Taiji, } \\
\text { Japan }\end{array}$ & $7.02(0.46-15.7)$ & - & - & Honda et al. (1983) \\
\hline & $\begin{array}{l}\text { Taiji \& Kii Peninsula, } \\
\text { Japan }\end{array}$ & $(2.05-22.2)$ & - & $(0.47-4.99)$ & Itano et al. (1985) \\
\hline & $\begin{array}{l}\text { Mediterranean, France } \\
(1973-1974)^{*}\end{array}$ & $8.13(1.91-23)$ & - & 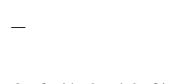 & Viale (1994) \\
\hline & Mediterranean, Italy* & $9.2(1.6-42.1)$ & - & $2.6(1.0-13.8)$ & Leonzio et al. (1992) \\
\hline & $\begin{array}{l}\text { Mediterranean, France } \\
(1988-1990)^{*}\end{array}$ & $11.2(1.85-38.9)$ & - & - & Augier et al. (1993) \\
\hline & $\begin{array}{l}\text { Mediterranean, France } \\
(1972-1980)^{*}\end{array}$ & $28.3(1.00-81.2)$ & - & - & Andre et al. (1990) \\
\hline S. longirostris & $\begin{array}{l}\text { Taiwan Strait \& SW } \\
\text { Pacific }\end{array}$ & $\begin{array}{l}1.39 \pm 0.30 \\
(0.84-1.76)\end{array}$ & $\begin{array}{l}1.13 \pm 0.32 \\
(0.59-1.60)\end{array}$ & $\begin{array}{l}1.54 \pm 0.41 \\
(1.01-2.40)\end{array}$ & This study \\
\hline \multirow[t]{4}{*}{ Tursiops truncatus } & $\begin{array}{l}\text { Taiwan Strait \& SW } \\
\text { Pacific }\end{array}$ & $\begin{array}{l}1.44 \pm 0.53 \\
(0.73-2.05)\end{array}$ & $\begin{array}{l}1.41 \pm 0.61 \\
(0.73-2.27)\end{array}$ & $\begin{array}{l}0.78 \pm 0.47 \\
(0.08-1.37)\end{array}$ & This study \\
\hline & Cardigan Bay, W. Wales* & 0.68 & - & - & Morris et al. (1989) \\
\hline & Australian waters & $(0.22-0.77)$ & - & - & Kemper et al. (1994) \\
\hline & Mediterranean, Italy* & $9.5(1.2-73.0)$ & - & $2.1(1.1-12.1)$ & Leonzio et al. (1992) \\
\hline
\end{tabular}

The asterisk $(*)$ indicates stranded specimens. The number in brackets indicate the range of values.

line established for the $\sum \mathrm{Hg}<4 \mathrm{mg} / \mathrm{kg}$ wet wt. for $S$. attenuata with that of $S$. longirostris shows that there was no significant difference between them (ANCOVA, $p>0.01$ ) (Fig. 4).

When the $\sum \mathrm{Hg}$ concentrations of the four species of small cetaceans were sorted in ascending sequence, the trend that emerged demonstrating that the percentage of
$\mathrm{O}-\mathrm{Hg}$ decreased to below $85 \%$ while the total $\mathrm{Hg}$ reached $\approx 4 \mathrm{mg} / \mathrm{kg}$ wet wt. in both females and males (Fig. 5).

Noteworthy too is that the percentage of $\mathrm{O}-\mathrm{Hg}$ was negatively correlated to the concentration of Se when the $\sum \mathrm{Hg}$ concentrations were greater than $4 \mathrm{mg} / \mathrm{kg}$ wet wt.; by contrast, when the $\sum \mathrm{Hg}$ concentrations were 


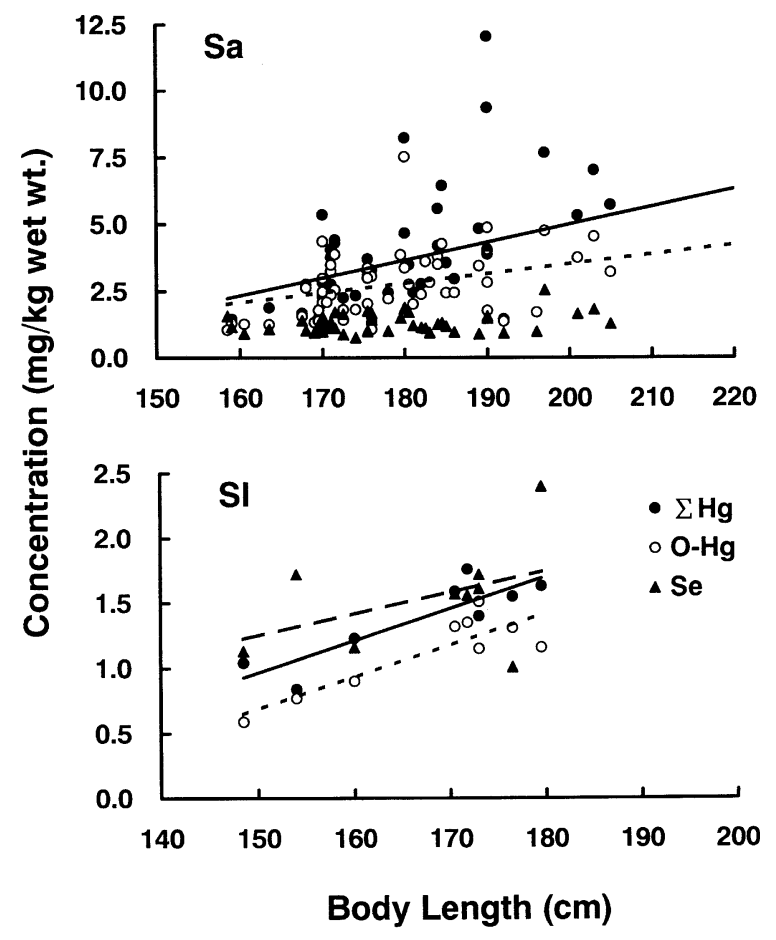

Fig. 3. Relationships between BL and $\sum \mathrm{Hg}, \mathrm{O}-\mathrm{Hg}$ and $\mathrm{Se}$ concentrations in the muscle tissues of $S$. atteunuata $(\mathrm{Sa})$ and $S$. longirostris (Sl) accidentally caught in Taiwanese waters.

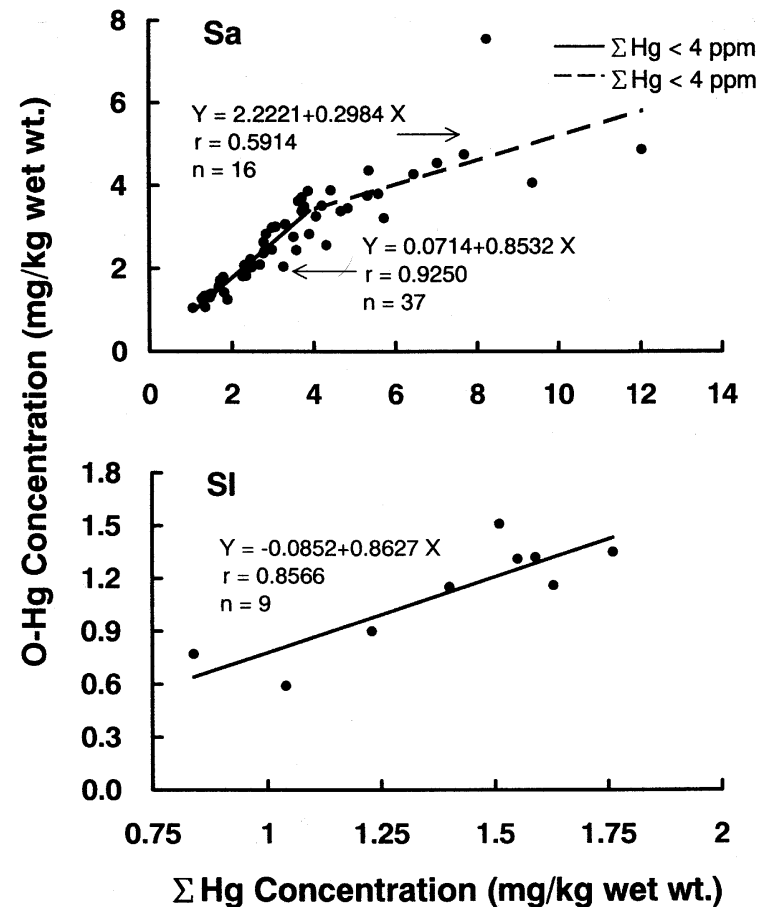

Fig. 4. Linear relationships between $\mathrm{\sum Hg}$ and $\mathrm{O}-\mathrm{Hg}$ concentrations $(\mathrm{mg} / \mathrm{kg}$ wet wt.) in the muscle tissues of $S$. atteunuata $(\mathrm{Sa})$ and $S$. longirostris $(\mathrm{Sl})$ accidentally caught in Taiwanese waters.

less than $4 \mathrm{mg} / \mathrm{kg}$ wet wt., the negative correlation was no longer found in the muscle tissues of the dolphin samples (Fig. 6).

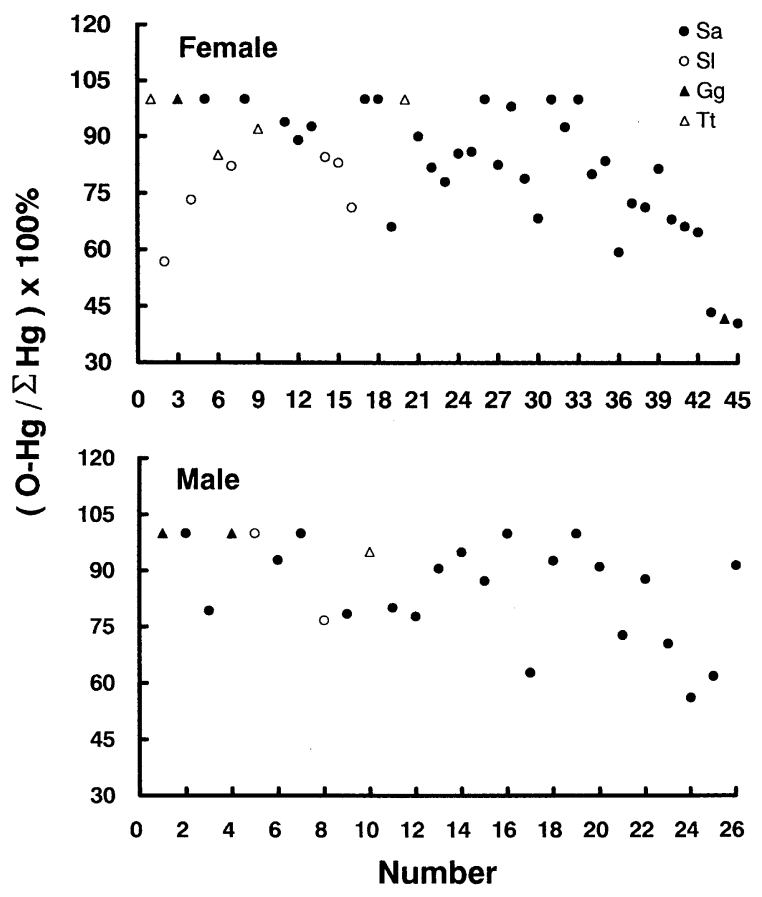

Fig. 5. Distribution of the percentage of $\mathrm{O}-\mathrm{Hg}\left(\mathrm{O}-\mathrm{Hg} / \sum \mathrm{Hg} \%\right)$ plotted in ascending order of the $\sum \mathrm{Hg}$ concentrations of males and females in the four species of small cetaceans. (The original data are listed in Tables 3 and 4.)

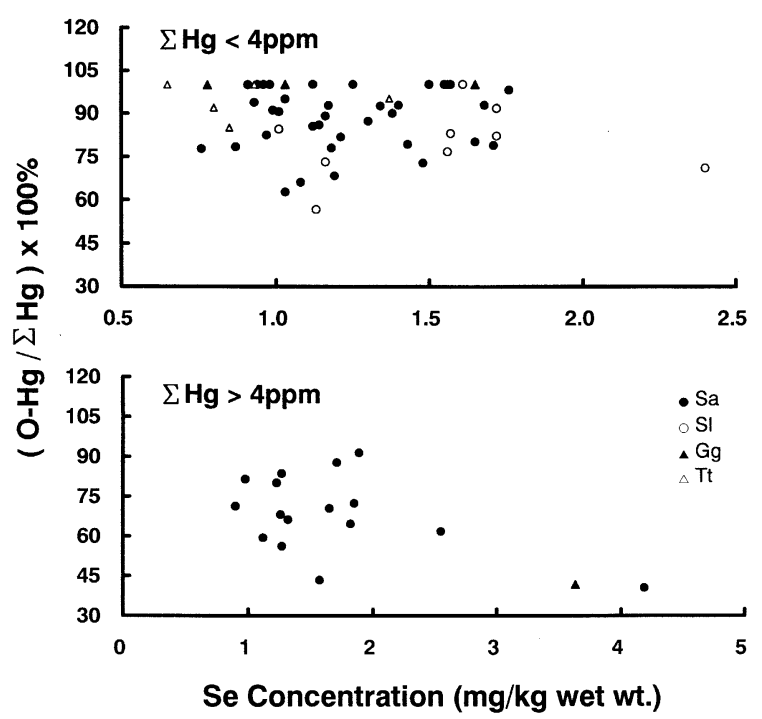

Fig. 6. Relationships between the Se concentrations $(\mathrm{mg} / \mathrm{kg}$ wet wt.) and $\mathrm{O}-\mathrm{Hg} / \sum \mathrm{Hg} \%$ in the two groups of dolphins based on whether the $\sum \mathrm{Hg}$ concentration was more or less than $4 \mathrm{mg} / \mathrm{kg}$ wet wt. in the muscle tissues.

\section{Discussion}

The factors influencing the species differences with respect to $\sum \mathrm{Hg}, \mathrm{O}-\mathrm{Hg}$ and $\mathrm{Se}$ concentrations in the four species of dolphins include age, feeding habits, 
availability of food, the amount of food-intake and habitat. The $T$. truncatus examined in this study were between 197 and $247 \mathrm{~cm}$ in length. They were in the young stage of bottlenose dolphins, which means they witnessed the shortest exposure time. Accordingly, they had the lowest metal bioaccumulations among the four species.

The length of G. griseus ranged from 179 to $272 \mathrm{~cm}$. They were also in the young stage of Risso's dolphins. They had different feeding habits from the other three species in that they ate more cephalopod and crustacean than the other species (Mr. M.-C. Wang, personal communication).

The size of $S$. longirostris and $S$. attenuata examined in this study covered the ranges of $148-180 \mathrm{~cm}(167 \pm 11$ $\mathrm{cm})$ and $158-205 \mathrm{~cm}(178 \pm 11 \mathrm{~cm})$, respectively, and the samples included both young and mature individuals. Although their ages and growth rates were unknown,the larger size of $S$. attenuata may consumed more food than $S$. longirostris thus, they would have taken in more

Table 3

List of the total $\mathrm{Hg}\left(\sum \mathrm{Hg}\right)$, organic- $\mathrm{Hg}(\mathrm{O}-\mathrm{Hg})$ and Se concentrations $(\mathrm{mg} / \mathrm{kg}$ wet wt.) as well as the percentage of $\mathrm{O}-\mathrm{Hg}(\mathrm{O}-\mathrm{Hg} \%)$ in the females of four species of dolphins based on the ascending order of $\left(\sum \mathrm{Hg}\right)$

\begin{tabular}{|c|c|c|c|c|c|c|c|c|c|}
\hline No. & Species Code & Site & $\mathrm{BL}(\mathrm{cm})$ & BW (kg) & Age (year) & $\sum \mathrm{Hg}$ & $\mathrm{O}-\mathrm{Hg}$ & $\mathrm{O}-\mathrm{Hg}^{0} \%$ & $\mathrm{Se}$ \\
\hline 1 & $\mathrm{Tt}$ & SU & 198.5 & 91.0 & - & 0.73 & 0.73 & 100 & 0.65 \\
\hline 2 & $\mathrm{~S} l$ & TG & 154.0 & - & - & 0.84 & 0.77 & 92 & 1.72 \\
\hline 3 & $\mathrm{Gg}$ & SU & 180.5 & 74.0 & - & 0.84 & 0.84 & 100 & 1.65 \\
\hline 4 & $\mathrm{Sl}$ & TG & 148.5 & 37.0 & - & 1.04 & 0.59 & 57 & 1.13 \\
\hline 5 & $\mathrm{Sa}$ & TG & 158.5 & - & - & 1.05 & 1.05 & 100 & 1.57 \\
\hline 6 & $\mathrm{Tt}$ & SU & 247.0 & - & - & 1.21 & 1.03 & 85 & 0.85 \\
\hline 7 & Sl & SU & 160.0 & - & - & 1.23 & 0.90 & 73 & 1.16 \\
\hline 8 & $\mathrm{Sa}$ & TG & 169.0 & 48.4 & - & 1.33 & 1.33 & 100 & 0.94 \\
\hline 9 & $\mathrm{Tt}$ & SU & 244.0 & - & - & 1.38 & 1.27 & 92 & 0.80 \\
\hline 10 & $\mathrm{Sl}$ & TG & 173.0 & 48.2 & - & 1.40 & 1.15 & 82 & 1.72 \\
\hline 11 & $\mathrm{Sa}$ & SU & 192.0 & 63.0 & 8 & 1.46 & 1.37 & 94 & 0.93 \\
\hline 12 & $\mathrm{Sa}$ & TG & 159.0 & - & - & 1.46 & 1.30 & 89 & 1.16 \\
\hline 13 & $\mathrm{Sa}$ & TG & 169.5 & 54.0 & - & 1.50 & 1.39 & 93 & 1.17 \\
\hline 14 & $\mathrm{Sl}$ & $\mathrm{CY}$ & 176.5 & 48.4 & - & 1.55 & 1.31 & 85 & 1.01 \\
\hline 15 & $\mathrm{Sl}$ & $\mathrm{CY}$ & 170.5 & 53.0 & - & 1.59 & 1.32 & 83 & 1.57 \\
\hline 16 & $\mathrm{Sl}$ & TG & 179.5 & 48.0 & - & 1.63 & 1.16 & 71 & 2.40 \\
\hline 17 & $\mathrm{Sa}$ & SU & 190.0 & - & 4 & 1.78 & 1.78 & 100 & 1.56 \\
\hline 18 & $\mathrm{Sa}$ & TG & 169.5 & 54.0 & - & 1.79 & 1.79 & 100 & 1.25 \\
\hline 19 & $\mathrm{Sa}$ & TG & 163.5 & 51.0 & - & 1.89 & 1.25 & 66 & 1.08 \\
\hline 20 & $\mathrm{Tt}$ & SU & 232.0 & 149.0 & - & 2.05 & 2.05 & 100 & 0.93 \\
\hline 21 & $\mathrm{Sa}$ & SU & 170.0 & 47.0 & 3 & 2.30 & 2.07 & 90 & 1.38 \\
\hline 22 & $\mathrm{Sa}$ & TG & 181.0 & 50.0 & - & 2.47 & 2.02 & 82 & 1.21 \\
\hline 23 & $\mathrm{Sa}$ & SU & 170.5 & - & - & 2.68 & 2.09 & 78 & 1.18 \\
\hline 24 & $\mathrm{Sa}$ & SU & 171.0 & 60.0 & 6 & 2.76 & 2.36 & 86 & 1.12 \\
\hline 25 & $\mathrm{Sa}$ & SU & 182.0 & - & 3 & 2.78 & 2.39 & 86 & 1.14 \\
\hline 26 & $\mathrm{Sa}$ & SU & 183.0 & - & 5 & 2.83 & 2.83 & 100 & 0.94 \\
\hline 27 & $\mathrm{Sa}$ & SU & 186.0 & - & 5 & 2.97 & 2.45 & 82 & 0.97 \\
\hline 28 & $\mathrm{Sa}$ & TG & 175.5 & - & - & 3.06 & 3.00 & 98 & 1.76 \\
\hline 29 & $\mathrm{Sa}$ & SU & 180.5 & - & - & 3.50 & 2.76 & 79 & 1.71 \\
\hline 30 & $\mathrm{Sa}$ & SU & 185.0 & - & 6 & 3.57 & 2.44 & 68 & 1.19 \\
\hline 31 & $\mathrm{Sa}$ & SU & 242.0 & - & - & 3.71 & 3.71 & 100 & 0.96 \\
\hline 32 & $\mathrm{Sa}$ & YL & 171.0 & - & - & 3.77 & 3.49 & 93 & 1.34 \\
\hline 33 & $\mathrm{Sa}$ & SU & 179.5 & - & 9 & 3.86 & 3.86 & 100 & 1.50 \\
\hline 34 & $\mathrm{Sa}$ & SU & 171.0 & - & 5 & 4.06 & 3.25 & 80 & 1.23 \\
\hline 35 & $\mathrm{Sa}$ & SU & 184.0 & - & 6 & 4.20 & 3.51 & 84 & 1.27 \\
\hline 36 & $\mathrm{Sa}$ & SU & 171.5 & 56.0 & 4 & 4.31 & 2.56 & 59 & 1.12 \\
\hline 37 & $\mathrm{Sa}$ & SU & 180.0 & 65.0 & 5 & 4.67 & 3.38 & 72 & 1.85 \\
\hline 38 & $\mathrm{Sa}$ & SU & 189.0 & - & - & 4.84 & 3.45 & 71 & 0.90 \\
\hline 39 & $\mathrm{Sa}$ & TG & 170.0 & 53.8 & - & 5.35 & 4.36 & 82 & 0.98 \\
\hline 40 & $\mathrm{Sa}$ & SU & 184.0 & - & 6 & 5.58 & 3.80 & 68 & 1.26 \\
\hline 41 & $\mathrm{Sa}$ & SU & 184.5 & - & 5 & 6.45 & 4.27 & 66 & 1.32 \\
\hline 42 & $\mathrm{Sa}$ & SU & 203.0 & - & 10 & 7.02 & 4.54 & 65 & 1.82 \\
\hline 43 & $\mathrm{Sa}$ & SU & 190.0 & - & 11 & 9.36 & 4.06 & 43 & 1.57 \\
\hline 44 & $\mathrm{Gg}$ & SU & 272.0 & 249.7 & - & 9.70 & 4.05 & 42 & 3.63 \\
\hline 45 & $\mathrm{Sa}$ & SU & 190.0 & 51.0 & 15 & 12.03 & 4.87 & 40 & 4.19 \\
\hline
\end{tabular}

Tt: T. truncatus; Sl: S. longirostris; Gg: G. giseus; and Sa: S. atteunuata. SU: Suao; TG: Tungkang; CY: Chengkung and YL: Yunlin. '-' means the data is unavailable. 
$\mathrm{NHg}$ and $\mathrm{O}-\mathrm{Hg}$. Moreover, the coastal-offshore migratory habit of $S$. attenuata could be another factor that caused this species to have greater exposure to higher doses of anthropogenic contaminants. Of course, the difference in dietary composition could also have been a major factor affecting the mercury bioaccumulation of organisms living in the same ecosystem (Monteiro et al., 1998).

The effect of gender in the bioaccumulation of $\sum \mathrm{Hg}$, $\mathrm{O}-\mathrm{Hg}$ and $\mathrm{Se}$ in small cetaceans in this study coincided closely with findings in other studies; however, they contradicted the findings of Andre et al. (1991) who found that the females of $S$. attenuata contained higher $\mathrm{Hg}$ concentrations than did the males.

According to some previous studies, stranded dolphins usually contain more elevated $\mathrm{Hg}$ concentrations than do by-catch dolphins (Table 2). In this study, we had only two stranded samples, and they revealed no specific elevated metal levels. The small size of the sample here may account for this discrepancy with other research findings.

It is widely accepted that $\sum \mathrm{Hg}$ and $\mathrm{O}-\mathrm{Hg}$ concentrations are positively correlated to the size of dolphins (Leonzio et al., 1992; Andre et al., 1991; Honda et al., 1983). The results in this study once again confirm this trend.
Our results indicated that the accumulations of $\sum \mathrm{Hg}$ in the muscle tissues of the small cetacean reached a turning point at about $4 \mathrm{mg} / \mathrm{kg}$ wet wt. Before reaching this point, the amount of $\mathrm{O}-\mathrm{Hg}$ in the muscle tissue of the dolphin seemed increase at the rate of about $85 \%$ accompanying with the increase of $\sum \mathrm{Hg}$. It would have then slowed down to only $30 \%$ when the $\sum \mathrm{Hg}$ in the muscle was over $4 \mathrm{mg} / \mathrm{kg}$ wet wt. It seems that demethylation was activated at the point, at which the lengths of the dolphins were $\mathrm{BL}=185$ and $273 \mathrm{~cm}$ in $S$. attenuata and $S$. longirostris respectively according to the regression lines established in Fig. 3.

Demethylation in the cetacean included the formation of metallothioneins and insoluble tiemannite. From the original data presented in Tables 3 and 4, the higher Se concentrations were found in samples with elevated $\sum \mathrm{Hg}$ but low $\mathrm{O}-\mathrm{Hg} \%$. This clearly shows that the formation of tiemannite was particularly active when the concentrations of $\sum \mathrm{Hg}$ in the muscle were greater than $4 \mathrm{mg} / \mathrm{kg}$ wet wt. It might be reasonable to assume that the protective mechanism of tiemannite has a similar function to the liver of dolphin in the study of Palmisano et al. (1995).

The $\mathrm{Hg}$ bioaccumulated in the toothed cetaceans represent the total exposure and the degree environmental degradation (Viale, 1994). In this study, the

Table 4

List of the total $\mathrm{Hg}\left(\sum \mathrm{Hg}\right)$, organic- $\mathrm{Hg}(\mathrm{O}-\mathrm{Hg})$ and $\mathrm{Se}$ concentrations $(\mathrm{mg} / \mathrm{kg}$ wet wt.) as well as the percentage of $\mathrm{O}-\mathrm{Hg}(\mathrm{O}-\mathrm{Hg} / 0)$ in the males of four species of dolphins based on the ascending order of $\sum \mathrm{Hg}$

\begin{tabular}{|c|c|c|c|c|c|c|c|c|c|}
\hline No. & $\begin{array}{l}\text { Species } \\
\text { code }\end{array}$ & Site & $\mathrm{BL}(\mathrm{cm})$ & BW (kg) & Age (year) & $\sum H g$ & $\mathrm{O}-\mathrm{Hg}$ & $\mathrm{O}-\mathrm{Hg}^{0} \%$ & $\mathrm{Se}$ \\
\hline 1 & $\mathrm{Gg}$ & SU & 179.0 & 87.0 & - & 0.71 & 0.71 & 100 & 0.78 \\
\hline 2 & $\mathrm{Sa}$ & TG & 160.5 & 47.0 & - & 1.27 & 1.27 & 100 & 0.91 \\
\hline 3 & $\mathrm{Sa}$ & SU & 176.0 & - & 4 & 1.35 & 1.07 & 79 & 1.43 \\
\hline 4 & $\mathrm{Gg}$ & CY & 233.5 & 164.4 & - & 1.44 & 1.44 & 100 & 1.03 \\
\hline 5 & $\mathrm{Sl}$ & SU & 173.0 & 35.0 & - & 1.51 & 1.51 & 100 & 1.61 \\
\hline 6 & $\mathrm{Sa}$ & $\mathrm{TG}$ & 167.5 & - & - & 1.68 & 1.56 & 93 & 1.40 \\
\hline 7 & $\mathrm{Sa}$ & YL & 196.0 & - & - & 1.71 & 1.71 & 100 & 0.98 \\
\hline 8 & $\mathrm{~S} 1$ & YL & 171.8 & - & - & 1.76 & 1.35 & 77 & 1.56 \\
\hline 9 & $\mathrm{Sa}$ & YL & 172.5 & - & - & 1.81 & 1.42 & 78 & 0.87 \\
\hline 10 & $\mathrm{Tt}$ & SU & 197.0 & - & - & 1.85 & 1.76 & 95 & 1.37 \\
\hline 11 & $\mathrm{Sa}$ & YL & 172.5 & - & - & 2.26 & 1.81 & 80 & 1.65 \\
\hline 12 & $\mathrm{Sa}$ & SU & 174.0 & - & 2 & 2.34 & 1.82 & 78 & 0.76 \\
\hline 13 & $\mathrm{Sa}$ & $\mathrm{TG}$ & 178.0 & 48.0 & - & 2.45 & 2.22 & 91 & 1.01 \\
\hline 14 & $\mathrm{Sa}$ & SU & 168.0 & 51.5 & 4 & 2.77 & 2.63 & 95 & 1.03 \\
\hline 15 & $\mathrm{Sa}$ & $\mathrm{TG}$ & 170.0 & 58.0 & - & 2.84 & 2.48 & 87 & 1.30 \\
\hline 16 & $\mathrm{Sa}$ & SU & 170.0 & 56.0 & 4 & 2.98 & 2.98 & 100 & 1.55 \\
\hline 17 & $\mathrm{Sa}$ & $\mathrm{TG}$ & 175.5 & 51.0 & - & 3.25 & 2.04 & 63 & 1.03 \\
\hline 18 & $\mathrm{Sa}$ & SU & 176.0 & 61.8 & 3 & 3.30 & 3.06 & 93 & 1.68 \\
\hline 19 & $\mathrm{Sa}$ & SU & 182.5 & - & 3 & 3.62 & 3.62 & 100 & 1.12 \\
\hline 20 & $\mathrm{Sa}$ & $\mathrm{SU}$ & 175.5 & - & 3 & 3.71 & 3.38 & 91 & 0.99 \\
\hline 21 & $\mathrm{Sa}$ & SU & 190.0 & 68.0 & 7 & 3.89 & 2.83 & 73 & 1.48 \\
\hline 22 & $\mathrm{Sa}$ & SU & 171.5 & - & - & 4.42 & 3.88 & 88 & 1.71 \\
\hline 23 & $\mathrm{Sa}$ & SU & 201.0 & - & - & 5.32 & 3.75 & 75 & 1.65 \\
\hline 24 & $\mathrm{Sa}$ & SU & 205.0 & - & 12 & 5.72 & 3.21 & 56 & 1.27 \\
\hline 25 & $\mathrm{Sa}$ & SU & 197.0 & - & - & 7.68 & 4.75 & 62 & 2.55 \\
\hline 26 & $\mathrm{Sa}$ & $\mathrm{SU}$ & 180.0 & - & 14 & 8.23 & 7.53 & 91 & 1.89 \\
\hline
\end{tabular}

Tt: T. truncatus; Sl: S. Longirostris; Gg: G. giseus; and Sa: S. atteunuata. SU: Suao; TG: Tungkang; CY: Chengkung and YL: Yunlin. '-' means the data is unavailable. 
mean $\sum \mathrm{Hg}$ concentration of $S$. attenuata was 1.5 and 3.0 times higher than these in the eastern Pacific and Australian waters (Kemper et al., 1994; Andre et al., 1991), respectively. Meanwhile, the Hg concentration in T. truncates found in this study is also two to three folds of the Australian bottlenose dolphin. However, these $\mathrm{Hg}$ concentrations in muscles were only one-eighth to onethird of the stranded dolphins off the Mediterranean coasts of Italy and France, and in the Atlantic (Storelli et al., 1998; Augier et al., 1993; Leonzio et al., 1992; Andre et al., 1991) (Table 2). It seems that the Hg levels of the small-toothed cetaceans in Taiwanese waters did not revealed a highly elevated concentrations. Taiwan is mountainous volcanic island, and is well industrialized with dense population. Either natural emissions from actively volcanic activities (Andersen and Depledge, 1997) or anthropogenic pollution could introduce mercury into the aquatic environments. Nevertheless, in the coastal waters of Taiwan, no observation of mercury pollution has ever been reported. So far, we suggest that the metal concentrations determined in this study could represent the present the baseline metal concentrations of marine mammals in the southwestern Pacific Ocean at present.

\section{Acknowledgements}

The authors are greatly indebted to Messrs. MingChih Wang, Hung-Ta Wu and Feng-Sheng Hsu for their careful work in sampling and sample pretreatment. Thanks are also expressed to the ICP-MS Laboratory headed by Prof. Shie-Jeng Cheng, Department of Chemistry, National Sun Yat-sen University, for their kind help in selenium analysis with the ICP-MS. This work was supported by funding from the National Science Council (project nos. NSC 87-2822-B-110-0003 and NSC 88-2621-Z-110-005) and the Fisheries Administration of Taiwan (project nos. 89-AST-1.2-FID-02(04) and 90 AS-1.4.5-FA-F1(27-3)).

\section{References}

Andersen, J.L., Depledge, M.H., 1997. A survey of total mercury and methylmercury in edible fish and invertebrates from Azorean waters. Marine Environmental Research 44, 331-350.

Andre, J.M., Ribeyre, F., Boudou, A., 1990. Mercury contamination levels and distribution in tissues and organs of Delphinids (Stenella attenuata) from the Eastern Tropical Pacific, in relation to biological and ecological factors. Marine Environmental Research 30, 43-76.

Andre, J.M., Ribeyre, F., Boudou, A., 1991. Mercury accumulation in Delphinidae. Water, Air and Soil Pollution 56, 187-201.

Augier, H., Park, W.K., Ronneau, C., 1993. Mercury contamination of the striped dolphin Stenella coeruleoalba from the French Mediterranean coasts. Marine Pollution Bulletin 26, 306311 .
Bargagli, R., Monaci, F., Sanches-Hernandez, J.C., Cateni, D., 1998. Biomagnification of mercury in an Antartic marine coastal food web. Marine Ecology Progress Series 169, 65-76.

Becker, D.S., Bigham, G.N., 1995. Distribution of mercury in the aquatic food web of Onondaga Lake, New York. Water, Air and Soil Pollution 80, 563-571.

Becker, P.R., 2000. Concentration of chlorinated hydrocarbons and heavy metals in Alaska Arctic marine mammals. Marine Pollution Bulletin 40, 819-829.

Chen, M.-H., Chou, C.L., 2000. An instrumental corrective method for determination of mercury in biological and sediment samples using cold vapor atomic absorption spectrophotometry. Journal of Chinese Chemistry Society 45, 1-9.

Fujise, Y., Honda, K., Tatsukawa, R., Mishima, S., 1988. Tissue distribution of heavy metals in Dall's porpoise in the northwestern Pacific. Marine Pollution Bulletin 19, 226-230.

Holsbeek, L., Siebert, U., Joiris, C.R., 1998. Heavy metals in dolphins stranded on the French Atlantic coast. The Science of Total Environment 217, 241-249.

Honda, K., Tatsukawa, R., Itano, K., Miyazaki, N., Fujiyama, T., 1983. Heavy metal concentrations in muscle, liver and kidney tissue of striped dolphins, Stenella coeruleoalba, and their variations with body length, weight, age and sex. Agricultural Biology and Chemistry 47, 1219-1228.

Itano, K., Kawai, S., Tatsukawa, R., 1985. Distribution of mercury and selenium in the muscle of striped dolphin. Agricultural and Biological Chemistry 49, 515-517.

Kemper, C., Gibbs, P., Obendorf, D., Marvanek, S., Lenghaus, C., 1994. A review of heavy metal and organochlorine levels in marine mammals in Australia. The Science of Total Environment 154, $129-139$.

Law, R.J., Fileman, C.F., Hopkins, A.D., Backer, J.R., Harwood, J., Jacksons, D.B., Kennedy, S., Martin, A.R., Morris, R.J., 1991. Concentrations of trace metals in the livers of marine mammals (seals, porpoises and dolphins) from waters around the British Isles. Marine Pollution Bulletin 22, 183-191.

Leonzio, C., Focardi, S., Fossi, C., 1992. Heavy metals and selenium in stranded dolphins of the Northern Tyrrhenian (NW Mediterranean). The Science of Total Environment 119, 77-84.

Marcovecchio, J.E., Moreno, V.J., Bastida, R.O., Gerpe, M.S., Rodriguez, D.H., 1990. Tissue distribution of heavy metals in small cetaceans from the southwestern Atlantic Ocean. Marine Pollution Bulletin 21, 299-304.

Marcovecchio, J.E., Gerpe, M.S., Bastida, R.O., Rodriguez, D.H., Moron, S.G., 1994. Environmental contamination and marine mammals in coastal waters from Argentina: an overview. The Science of Total Environment 154, 141-151.

Miyazaki, N., 1994. Contaminant monitoring studies using marine mammals and the need for the establishment of an international environmental specimen bank. The Science of Total Environment $154,249-256$.

Monteiro, L.R., Grandadeiro, J.R., Furness, R.W., 1998. Relationship between mercury levels and diet in Azores seabirds. Marine Ecology Progress Series 166, 259-265.

Morris, R.J., Law, R.J., Allchin, C.R., Kelly, C.A., Fileman, C.F., 1989. Metals and organochlorines in dolphins and porpoises of Cardigan Bay, West Wales. Marine Pollution Bulletin 20, 512 523.

Muir, D.C.G., Wagemann, R., Grift, N.P., Norstrom, R.J., Simon, N., Lein, J., 1988. Organochlorine chemical and heavy metal contaminants in white-beaked dolphins (Lagenorhynchus albirostris) and pilot whales (Globicephala melaena) from the coast of Newfoundland, Canada. Archives of Environmental Contamination and Toxicology 17, 613-629.

Noda, K., Ichihashi, H., Loughlin, T.R., Back, N., Kiyota, M., Tatsukawa, R., 1995. Distribution of heavy metals in muscle, liver and kidney of northern fur seal (Callorhinus ursinus) caught off 
Sanriku, Japan and from the Pribilof islands, Alaska. Environmental Pollution 90, 51-59.

Palmisano, F., Cardellicchio, N., Zambonin, P.G., 1995. Speciation of mercury in dolphin liver: a two-stage mechanism for the demethylation accumulation process and role of selenium. Marine Environmental Research 40, 109-121.

Parsons, E.C.M., 1999. Trace element concentrations in the tissues of cetaceans from Hong Kong's territorial waters. Environmental Conservation 26, 30-40.

SAS, 1988. Statistical Analysis Software Institute Inc. SAS/STAT ${ }^{\circledR}$ user's, Release 6.03, ed. SAS Institute Inc., 1028 pp. Cary.

Shum, G.T.C., Freeman, H.C., Uthe, J.F., 1979. Determination of organic (methyl) mercury in fish by graphite furnace atomic absorption spectrophotometry. Analytical Chemistry 51, 414-416.

Siebert, U., Joiris, C., Holsbeek, L., Benkes, H., Failing, K., Frese, K., Petzinger, E., 1999. Potential relation between mercury concentrations and necropsy findings in cetaceans from German waters off the North and Baltic Seas. Marine Pollution Bulletin 38, 285-295.

Storelli, M.M., Ceci, E., Macrotrigiano, G.O., 1998. Comparison of total mercury, methylmercury and selenium in muscle tissues and in the liver of Stenella coeruleoalba (Meyen) and Caretta caretta (Linnaeus). Bulletin of Environmental Contamination and Toxicology 61, 541-547.

Uthe, J.F., Armstrong, F.A.J., Stainton, M.P., 1970. Mercury determination in fish samples by wet digestion and flameless atomic absorption spectrophotometry. Journal of Fisheries Research Board of Canada 27, 805-811.

Uthe, J.F., Solomon, F., Grift, B., 1972. Rapid semimicro method for the determination of methyl mercury in fish tissues. Journal of Association and Official Analytical Chemistry 55, 583-589.

Viale, D., 1994. Cetaceans as indicators of a progressive degradation of Mediterranean water quality. International Journal of Environmental Study 45, 183-198.

Wagemann, R., Innes, S., Richard, P.R., 1996. Overview and regional and temporal differences of heavy metal in Arctic whales and ringed seals in the Canadian Arctic. The Science of Total Environment $186,41-66$

Wood, C.M., Vleet, E.S., 1996. Copper, cadmium and zinc in liver, kidney and muscle tissues of bottlenose dolphins (Tursiops truncatus) stranded in Florida. Marine Pollution Bulletin 32, 886-889. 